\title{
Otsides „müstilist miskit": millest koosneb kooli maine?
}

\author{
Mari-Liis Tikerperi ${ }^{\text {al }}$ \\ ${ }^{a}$ Tartu Ülikooli ühiskonnateaduste instituut
}

\begin{abstract}
Annotatsioon
Kooli maine on leidnud Eesti üldhariduse kontekstis käsitlemist kui koondmõiste, mis määrab kooli positsiooni abstraktses võrdluses teistega. Teoreetilised lähenemised näevad maine seoseid organisatsiooni identiteediga ja mainekujundust osana organisatsiooni juhtimisest. Muutunud ühiskondlikud nõudmised ja nüüdisaja meediaruum on koolijuhtimisse toonud muu hulgas vajaduse olla nähtav ning kujundada oma tegevust huvirühmade ootuste järgi. Kvalitatiivse uuringu eesmärk oli välja selgitada, millised indikaatorid loovad koolijuhtide $(\mathrm{N}=19)$ hinnangul arusaama kooli mainest ning millised on koolide kogemused mainekujundusega. Olulise tulemusena võib näha, et kooli maine ei ole konstantne väärtus, vaid sõltub üldiselt pikemast ajalisest faktorist ja maine tajuja positsioonist huvirühmade koosseisus. Maine teadlikumaks kujundamiseks pole aga alati piisavalt vahendeid ega oskusi ning osa mainekujunduslikest katsumustest on seotud hoopis kooliväliste teguritega.
\end{abstract}

Võtmesõnad: kooli maine, üldhariduskool, kooliga rahulolu, koolijuhtimine, kooli kommunikatsioonijuhtimine

\section{Sissejuhatus}

Igapäevaelus kasutatakse maine (ka reputatsiooni, imago ja kuvandi) mõistet sageli sotsiaalsete suhetega seonduva abstraktse hinnanguna, mida rakendatakse nii inimeste kui ka institutsioonide iseloomustamisel. Teisisõnu mõistetakse maine all peamiselt seda, kuidas seotud indiviidid ja huvirühmad isikut või organisatsiooni tajuvad ning tema või selle tegevust hindavad (da Camara, 2011). Teaduskirjanduses on maineuuringud seotud rohkem kommunikatsiooniga turunduse, poliitika, organisatsioonikultuuri ja juhtimise valdkondades (da Camara, 2011; Skallerud, 2011). Olgugi et üldhariduskoolidele keskendunud maineuuringuid leiab vähem, on siiski täheldatud hea maine positiivset efekti ka koolidele (Skallerud, 2011), sest põhimõtted suhete 
loomiseks ja hoidmiseks organisatsioonile oluliste huvirühmadega on universaalsed (Moss \& DeSanto, 2011).

Konkreetsete teadusuuringute vähesusest hoolimata võib täheldada, et Eesti hariduskontekstis on kooli maine levinud termin. Näiteks meedias on koolide kontekstis mainele viidatud kui kooli suurimale väärtusele, mille kujunemist seostatakse eelkõige akadeemiliste tulemustega (Heinaru, 2016; Kasemägi, 2018), kuid mõjuteguritena on välja toodud ka vilistlaste edukust ja häid olmetingimusi (Kasemägi, 2018). Samas esineb ka artikleid, kus kooli (halba) mainet esitatakse põhjendamata abstraktse hinnanguna (Aljas, 2013; Kukin, 2018). Lisaks on meedias palju kõneainet pälvinud õpetajaameti halb maine, mida kõige enam seotakse madala töötasuga (Salu, 2018).

Kuigi eelnevast võiks mõista, et kõik nimetatud aspektid mängivad kooli maine kujunemises rolli, seisavad Kessa (2013) uuritud koolivaliku kriteeriumides olmetingimused, akadeemilised tulemused ja hea maine eraldi. Innove rahuloluküsitlustes on maine seotud õpilaste, õpetajate ja lapsevanemate üldise rahuloluga (Lukk et al., 2016).

Oma igapäevatöös lähtuvad Eesti üldhariduskoolid riiklikest õppekavadest, mis seavad üldharidusele tsentraliseeritud eesmärgid. Ehkki saab eeldada, et kõik koolid ei täida neid eesmärke täpselt samade tulemustega, on riikliku üldharidusprogrammi põhimõte pakkuda võimalikult võrdse kvaliteediga haridust kõikidele õpilastele (HTM i.a). Õigupoolest nähtub rahvusvahelistest uuringutest (Hatzopoulos, Kollias, \& Kikis-Papadakis, 2015; OECD, 2009; OECD, 2014), et suureneva tsentraliseerimise kõrval on koolidel ka üha suurenev autonoomia ehk otsustusvabadus, kuidas eesmärkideni jõuda. Omajagu vastuolulisena mõjub seegi, et nüüdisaegselt koolilt oodatakse kohati nii traditsiooniliste ja hästimõistetavate lähenemiste säilitamist kui ka aja ja muutustega kaasaskäimist (Kuurme, 2007; Senge, 2009; Vinter 2014). Muu hulgas on muutunud käsitlused koolijuhtimisest, mis tähtsustavad üha enam koolijuhi individuaalseid üldjuhtimispädevusi, osutavad vähenenud koolikeskkonna spetsiifikale koolijuhtimises (Harris et al., 2003) ja näevad oluliselt suurenenud vajadust olla direktoril kooli esindaja väliste sihtrühmadega suheldes (Fullan, 2014; Ishaq \& Kritsonis, 2009; Porterfield \& Carnes, 2012). Ka avalik huvi koolides toimuva suhtes on märgatavalt kasvanud (Breiter \& Ruhe, 2018; Isaksson \& Enbom, 2015) ning tänapäeva infoühiskonnaga kaasuv muutunud meediakeskkond (Breiter \& Ruhe, 2018; Gilpin, 2010; Rawolle, 2010) nõuab juba iseenesest teadlikumat info haldamist.

Seega võib näha, et riiklikult ühtsete eesmärkidega töötavate koolide võrdlemine võib olla küsitava väärtusega. Teisalt on koolide autonoomia, kooliga seotud inimeste individuaalsed omadused, konkurents ja muutunud meedia loonud olukorra, kus tähtsad on kooli eripära, pakutav lisandväärtus 
haridusmaastikul ning selleüleselt ka oskus enda unikaalsust avalikkusele esitleda ja tõestada. Selle kõrval võib täheldada, et maine mõiste on üldhariduskoolide kontekstis kasutusel nii avalikus diskussioonis (Aljas, 2013; Heinaru, 2016; Kasemägi, 2018; Kukin, 2018; Salu, 2018), teadustöödes (Kessa, 2013; Skallerud, 2011) kui ka SA Innove rakendusuuringutes (nt Lukk et al., 2016), kuid eri vaatenurgad viitavad ühtse arusaama puudumisele mõiste sisus. Siinse artikli eesmärk on uurida üldhariduskoolide direktorite arusaamu kooli mainet kujundavatest aspektidest ja mainekujunduse olemusest koolikeskkonnas.

\section{Teoreetilised lähtekohad}

\section{Maine ja mainekujundus}

Maine defineerimisel leidub kirjanduses mitmesuguseid selgitusi ja seotud mõisteid, mida sageli kasutatakse sisuliselt sama nähtuse tähistamiseks. Kui inglise keeles on küsimus peamiselt mõistete reputation ja image (ka imago) kohati samatähenduslikus kasutamises (Gilpin, 2010), siis eesti keeles kasutatakse igapäevakeeles paralleelselt termineid reputatsioon ehk maine (teatud laadi kuulsus) ja kuvand ehk imago (esemest või nähtusest loodud kujutluspilt) (EKI, i.a). Samuti võib sarnases kontekstis leida mõisteid prestiiž (lugupeetavus, mõjukus) ja staatus (seisund, positsioon süsteemis) (EKI, i.a). Sisuliselt kujuneb maine planeeritud ja planeerimata sõnumitest, mida organisatsioon välja saadab, ning maine annab väärtuse organisatsioonilt saadavale teabele (Smith, 2009).

Mainest ja kuvandist rääkides puudutatakse sageli ka mõistet identiteet, mis viitab organisatsiooni enesemääratlemisele ja sellele, millisena tajuvad organisatsiooni selle liikmed (Brown, Dacin, Pratt, \& Whetten, 2006). Identiteedi mõtestamine keskendub viidatud uuringus küsimusele „Kes me organisatsioonina oleme?" (Brown et al., 2006), mis koosneb strateegilisest vaatest organisatsiooni käitumisele ja kultuurile ning organisatsiooni visuaalsest identiteedist (da Camara, 2011). Mõiste kuvand on sisuliselt identiteediga põimunud ning Brown jt (2006) jagavad selle omakorda kaheks seotud aspektiks: kavandatud kuvand ehk „Mida me tahame, et organisatsioonist arvatakse?" ja tõlgendatud kuvand ehk „Mida me usume, et organisatsioonist arvatakse?“. Maine on selles lähenemises selgitatud küsimuse „Mida välised huvirühmad tegelikult organisatsioonist arvavad?" kaudu (Brown et al., 2006).

Helm $(2011,1 k 7)$ on koondanud hulga autorite (Fombrun, Wartik, Wilson, Bromley, Post, Griffin jt) maine olemust kirjeldavad definitsioonid ja jõudnud kõiki aspekte hõlmava tõlgenduseni. Sellest lähtuvalt on maine huvirühmade üldine hinnang läbi aja (seos mineviku, oleviku ja tuleviku vahel), hõlmates 
suhteid (huvirühmadega), mis peegeldavad organisatsiooni võimekust ja tahet vastata endiselt huvirühmade ootustele, ning maine kirjeldab organisatsiooni üldist kasutegurit kõigile oma klientidele teiste sarnaste organisatsioonidega võrreldes (Helm, 2011). Lähtuvalt nimetatud tõlgenduse laiapõhjalisest taustast on kasutatud Helmi välja toodud aspekte ka siinse uuringu andmestiku analüüsis.

Kuna organisatsioonide jaoks on nende huvirühmad olulised, peavad nad lähtuvalt kollektiivsetest ootustest kohandama oma väljanäidatavat kuvandit (Gilpin, 2010) või pigem mõistma, et iga tegevus saadab huvirühmadele sõnumeid (Vaarik, 2014), mis kuvandit mõjutavad. Täidetud ootused aitavad mainet hoida ja parandada, täitmata ootused aga võivad mainet kahjustada (Vaarik, 2014). Seega seisneb mainekujunduse nagu iga muu kommunikatsiooniga tihedalt seotud valdkonna efektiivsus sihtrühmapõhisuses ja tegevusplaani arendamine algab just organisatsiooniga seotud inimrühmade huvide väljaselgitamisest (Moss \& DeSanto, 2011).

Lihtsamalt öeldes kujuneb maine aja jooksul sellest, kuidas ühtivad loodud kuvandid organisatsiooni identiteediga ning huvirühmade ootused organisatsiooniliikmete individuaalsete ja ühiste käitumisviisidega. Viimased on samuti osa kuvandiloomest ehk tähistavad tugevat seotust maine ja kuvandi vahel. Pea kõik eelmainitud autorid on nentinud, et kindlasti pole maine, kuvandi ja identiteediga seotud definitsioonid lõplikud ja lisauuringud võimaldavad neid mõisteid paremini selgitada.

\section{Maine koolide kontekstis ja muutunud vaated koolijuhtimisele}

Nagu eespool täheldatud, on maineuuringud tihedalt seotud valdkondadega, mida on varem seostatud pigem eraettevõtluse (turundusvaldkonna) või individuaalsel tasandil avaliku elu tegelastega. Samas tõid mõned autorid juba paarkümmend aastat tagasi välja, et koolijuhtimine sarnaneb üha enam ärijuhtimisega (Bush \& Bell, 2002; Fullan, 2001). Samuti on nüüdisaegsed lähenemised koolijuhtimisele nii rahvusvaheliselt kui ka Eestis paljuski seotud uue haldusjuhtimise ehk new public management'i (NPM) teooriaga, mis lühidalt seisneb selles, et avaliku sektori organisatsioonid, sealhulgas koolid, võtavad üle seni pigem erasektoris kasutatavaid juhtimispraktikaid ja -meetodeid (Breiter \& Ruhe, 2018; Türk et al., 2011). NPM on kaasa toonud ka suurema konkurentsiolukorra, mis tähendab eelkõige avaliku sektori teenuste kujundamisel ja pakkumisel seotud poolte ehk huvirühmade eelistustega arvestamist (Türk et al., 2011). Koolide omavahelise konkurentsi suurenemist haridusturul on välja toonud ka teised teadlased (Bunar \& Ambrose, 2016; Isaksson \& Enbom, 2015). 
OECD korraldatud TALISe (The Teaching and Learning International Survey) uuringud kinnitavad, et nüüdisaegsele koolile ja koolide juhtimisele esitatavad nõudmised on kõrgemad kui kunagi varem ja hariduse areng on rahvusvaheliselt aktuaalne teema (OECD, 2014; OECD, 2019). Muutustega kaasaskäimiseks peab tänapäeva koolijuht suutma kasutada väliseid ressursse kooli ja õpilaste arengu huvides (Fullan, 2014). Lisaks peab juht teadma, kuidas heade tulemuste saavutamiseks kaasata juhtimisse huvirühmi (Kukemelk \& Ginter, 2016), kuidas viia kõigini kooli eesmärgid ja visioon ning tegeleda muudatustega hariduses üldiselt (Ishaq \& Kritsonis, 2009), sest nüüdisaja koolijuht peaks kujunema laiemalt haridusjuhiks piirkonna ja süsteemi tasandil (Fullan, 2014). Sellest lähtub, et üldhariduskoolid peavad jagama teavet enda tegevuse kohta ja suhtlema oluliste huvirühmadega (Porterfield \& Carnes, 2012), kellena nähakse eelkõige õpilasi, õpetajaid (jt koolitöötajaid), lapsevanemaid ja koolipidajat (Breiter \& Ruhe, 2018; Skallerud, 2011).

Samas peavad koolid nagu kõik teisedki organisatsioonid arvesse võtma oma huvirühmade ja välismaailmaga suhtlemisel tehnoloogia ja eelkõige interneti arengust lähtuvaid muutusi kommunikatsiooniviisides ja -kanalites (Porterfield \& Carnes, 2012; Watson, 2012). Ühelt poolt näib, et tänapäeval on infot lihtsam edastada, ent teiselt poolt on fragmenteerunud meediaruumis keerulisem sihtrühmani jõuda (Gilpin, 2010) ja oma sõnumitega arusaadavalt mõjule pääseda (Koschmann, 2012).

Uue nähtusena on koolid mõjutatud ka meediastumisest (Breiter \& Ruhe, 2018), mis üldises plaanis tähendab meedia toimimise arusaamade ja mehhanismide levimist teistesse valdkondadesse. Koolide kontekstis saab meediastumist selgitada näitega, et oluline pole ainult tugev õppetöö või hästi korraldatud kooliüritus, vaid ka see, kuidas tehtut atraktiivselt esitleda, sest õigete kanalite kaudu, läbimõeldud visuaalse materjali ja sõnalise info abil on koolidel võimalik mõjutada huvirühmade hoiakuid ja suhtumist. Ehk siis vaadates maine definitsioone, kujundab koolide tegevus igal juhul nende mainet huvirühmade silmis. Lapsevanemate kui ühe huvirühma tajutud kooli mainet uurinud Skallerudi (2011) meelest ei saa aga koolid oma maine kujundamisega tegeleda, kui neil puuduvad mingilgi moel mõõdetavad näitajad.

Kui vaadelda meediastumise mõju haridusvaldkonnale üldisemalt, võib tekkida küsimus, kas koolidel on üldse võimalik igakülgselt oma mainega toimuvat ise kontrollida. Rawolle (2010) toob meediastumise juures välja, et vahendajad (nt ajakirjanikud, poliitikud, huvirühmade esindajad) võivad oma tegevuse ja sõnavõttudega avalikku arvamust mõjutada. Sel moel puudub koolidel sisuline kontroll teemade või vaatenurkade üle ning kajastatu võib (negatiivselt) mõjutada ka kooli mainet. 


\section{Hariduse ja üldhariduskoolide maine Eesti kontekstis}

Üldiselt võib täheldada, et hariduse maine tervikuna saab Eestis arvestatavat tähelepanu. Riiklikul tasandil tegeleb valdkonnaga Haridus- ja Teadusministeerium (HTM), mis eelkõige rahvusvahelise PISA uuringu kõrgetele tulemustele toetudes levitab tugeva Eesti hariduse edulugu ja koostöös SA Innovega koordineerib mainekujundus- ja haridusturundusprogrammi Education Nation ehk Haridusrahvas (Ots, 2019).

Viimastel aastatel on rohkem esile kerkinud ka üldhariduskoolide mainega seotud teemad. Suuresti SA Innove, kuid ka teiste üleriigiliste algatuste ja koostöövõrgustike eestvedamisel on tähelepanu pööratud konkreetsemalt õpetajaameti maine parandamisele ning haridusasutuste töötajatele korraldatakse nii piirkondlikke kui ka üleriigilisi koolitusi, mis puudutavad avalikku esinemist, efektiivset kommunikatsiooni ja isikubrändimist (Innove, i.a). Tartu Ülikooli eetikakeskuse eestvedamisel on ellu kutsutud tunnustusprogramm „Hea kool“, mille hindamiskriteeriumides võib täheldada sarnasusi maine definitsioonidega eelkõige suhete ehk sotsiaalsete aspektide ja kommunikatsiooni puhul (Sutrop, Toming, \& Kõnnussaar, 2017), kuigi programmijuhend mõistet maine ei puuduta. Lisaks on hea kooli juures olulisena nimetatud seotud poolte rahulolu, kooli pakutavad väärtused, hea õpikeskkond ja muud faktorid (Sutrop et al., 2017), mida on välja toodud ka maineteemasid käsitlevates ajaleheartiklites.

Konkreetsemalt koolide mainekujunduse olulisusest leiab viiteid riigigümnaasiumide kvaliteedikokkuleppes ja juhtide tööülesannetes (HTM, i.a; Tikerperi, 2016), kuid munitsipaalkoolidel vastav ühtne eesmärk puudub. Samas aitaksid ühtsed alused ja arusaamad tugevdada süsteemi, sest „kuigi oivaliseks kooliks on võimalik saada ümbritseva süsteemi kiuste, pole võimalik tõhusaks jääda, kui süsteem ei kultiveeri oivalisust kõigis oma koolides" (Fullan, 2014, lk 111). Riiklikult võib koolijuhi tasandil mainega seostada haridusjuhi kompetentsimudeli (Innove, 2016) punkti „Eduloo rääkimine“, mis eeldab kooli tegevuse tutvustamist huvirühmadele.

Peale eelmainitu tehakse SA Innove eestvedamisel üldhariduskoolide õpilaste (4., 8. ja 11. klassid), õpetajate ja lapsevanemate rahuloluküsitlusi, mille ühe osana püütakse mõõta ka koolide mainet ja palutakse vastajatel hinnata tabelis 1 toodud väiteid.

Uuringutest nähtub, et nooremad õpilased hindavad oma kooli mainet kõrgemalt kui vanemad õpilased, mis on seletatav kognitiivse arengu ja ealiste muutustega maailma tajumises (Valk, 2017). Üldiselt saab aga tõdeda, et vastused sõltuvadki konkreetse vastaja arusaamast ja tajust, sest täpsem selgitus, mis on maine, uuringus puudub ega ole selles kontekstis ka eesmärgipärane. Rahuloluküsitluse tulemuste raportid, kus võrreldakse kooli tulemusi riigi keskmiste tulemustega, edastatakse vaid koolidele ning nende eesmärk on toetada koolide arendustegevuse planeerimist. 
Tabel 1. SA Innove rahuloluküsitluse väited kooli maine hindamiseks

$\begin{array}{lll}\text { Õpilaste küsitluses } & \text { Õpetajate küsitluses } & \text { Lastevanemate küsitluses } \\ \begin{array}{lll}\text { a) Olen uhke, et õpin just selles } \\ \text { koolis. }\end{array} & \begin{array}{ll}\text { a) Meie koolil on hea maine. } \\ \text { b) Olen uhke, et töötan just }\end{array} & \begin{array}{l}\text { a) Olen rahul, et minu laps õpib } \\ \text { just selles koolis. }\end{array} \\ \begin{array}{lll}\text { b) Soovitaksin oma kooli ka } \\ \text { teistele õpilastele. }\end{array} & \begin{array}{l}\text { c) Soovitaksin siin töötamist ka } \\ \text { teistele õpetajatele. }\end{array} & \begin{array}{l}\text { boovitaksin oma lapse kooli } \\ \text { c) Minu koolistele. }\end{array}\end{array}$

Ühiskondlikus diskussioonis saab aga täheldada, et kooli maine on seostatud sageli akadeemiliste tulemuste ja gümnaasiumiastmega koolide puhul igaaastaste riigieksamite pingeridadega (Heinaru, 2016; Sutrop et al., 2017). Hea kooli käsiraamat rõhutab, et kuna riikliku õppekava eesmärkides on teadmiste kõrval ka kasvatuslik külg, ei saa kooli headust hinnata vaid akadeemiliste tulemuste järgi (Sutrop et al., 2017). Samal põhjusel arvutatakse SA Innoves gümnaasiumide lisandväärtuse näitajat (Must, 2016), mis ei keskendu üksnes konkreetsetele tulemustele, vaid pigem protsessi mõõtmisele.

Eelnevale toetudes saab täheldada, et üldhariduskoolidega ja üldiselt haridusega seotud maine on aktuaalne teema, kuid lähenemised sellele on erinevad. Selleks, et arendada ühtsemat sisulist arusaama maine olemusest, on kindlasti oluline teemat käsitleda nii teaduses kui ka praktilistes lähenemistes. Seega on siinse uurimuse eesmärk välja selgitada kooli mainet ehk kooli tegevuse tulemusena tajutavat väärtust mõjutavad aspektid ning analüüsi tulemusel pakkuda võimalusi, kuidas võiks praktikas indikaatorite abil tegeleda mainekujundusega üldhariduskoolis. Kuna mainekujundust vaadeldakse üldiselt osana organisatsiooni juhtimisest, tegi siinse uurimuse autor andmete kogumiseks intervjuud koolidirektoritega $(\mathrm{N}=19)$, et leida vastuseid järgmistele uurimisküsimustele:

1) Kuidas tajuvad ja kirjeldavad koolijuhid kooli mainet ja mainekujundust üldiselt?

2) Kuidas suhestuvad koolijuhtide kirjeldused kooli mainest teoreetiliste maine definitsioonidega?

\section{Metoodika}

\section{Valim ja andmestik}

Kuna üldhariduskoolide mainet ja laiemalt koolide avalikke suhteid pole Eestis põhjalikult uuritud ning ka hariduskommunikatsioon on arenev uurimisvaldkond, puuduvad uuritava teema kohta ühised arusaamad. Seega, et saada laiemapõhjalist infot ja temaatiliselt olulisi detaile, on valitud uuringu tegemiseks kvalitatiivne lähenemine. 
Valimi moodustamisel on rakendatud variatiivsuse põhimõtet, lähtudes eesmärgist kaasata uuringusse võimalikult eripalgeliste munitsipaalkoolide juhte $(\mathrm{N}=19)$. Mitmekesisuse kriteeriumist lähtudes olid olulised näitajad juhitava kooli

a) asukoht (maapiirkond, väikelinn, suurlinn);

b) õppeastmed (põhikool, täistsüklikool, gümnaasium);

c) teadaolevad eripärad (uuringus esindatud koolide profiilides kombineeritult: tugev haridusprogrammides osaleja, riigieksamite edetabelis kõrgel kohal, uus kool ehk nn nullkool, pika ajalooga kool, eristuv koolijuhi taust, spetsiifilised jooned, kohaliku haridusreformiga seotud - suletud või suletav gümnaasiumiaste vms);

d) suurus (uuringus koolid õpilaste arvuga $\mathrm{n}<100$ kuni $1000<\mathrm{n}$ ).

Mitme koolijuhi kaasamist saab vaadelda mugavusvalimina, lähtudes varasematest teadmistest kooli tegevuse kohta või ka olemasolevast kontaktist koolijuhiga. Samuti lisandus mõni koolijuht lumepallimeetodiga ehk juba osalenud direktorite soovituste kaudu. Soovitatud direktorite puhul oli muu hulgas oluline mõni spetsiifiline uuringus veel katmata nüanss. Kokkuvõttes saab öelda, et kõik kaasatud koolid ja koolijuhid olid unikaalsed vähemalt ühe nimetatud näitaja poolest.

Uuringus osalenud koolijuhtide tööstaaž juhina varieerub paarist aastast pea kolmekümne aastani. Valdav osa neist (18) on pedagoogilise hariduse ja õpetajakogemusega. Kõik intervjueeritavad on kokku puutunud koolijuhtide täienduskoolituste või tasemeõppega. Üldiselt saab osalenud koolijuhte iseloomustada kui kogukonnas aktiivseid ja teadlikke haridusvaldkonna eksperte, kellel on osalt ühised arusaamad nüüdisaegsest haridusest, kuid samal ajal erinevad töömeetodid organisatsioonikultuuri ülesehitamiseks ja igapäevatöös kasutatavad praktikad. Et tagada koolijuhtide anonüümsust, ei ole välja toodud koolijuhtide ega koolide individuaalseid profiile ja tulemustes esitatud tsitaatides on nad tähistatud koodidega KJ_1 kuni KJ_19.

Põhjaliku info ja erinevate kogemuste saamiseks andmete kogumisel tehti koolijuhtidega poolstruktureeritud intervjuud, mis võimaldasid järgida planeeritud kava, kuid vestluse dünaamikast lähtuvalt küsimusi kohandada (Lagerspetz, 2017). Intervjuude kavandamisel on toetutud varem riigigümnaasiumide juhtidega tehtud uuringule (Tikerperi, 2016), mille käigus analüüsiti suhtekorraldust tänapäeva kooli juhtimises, ning lisatud maine ja mainekujunduse fookusega küsimuste plokk, mis on aluseks siinsele artiklile. Intervjuudes käsitletud teemad olid:

a) koolidirektorite tajutud ühiskondlikud ootused nüüdisaegsele koolile ja koolijuhile; 
b) (välis)kommunikatsiooni korraldamine üldhariduskoolis (sh sihtrühmad, tööjaotus meeskonnas);

c) üldhariduskoolide maine, selle olulisus ja praktiline mainekujundus.

Intervjuud on tehtud 2019. aasta lõpul ja need kestsid keskmiselt poolteist tundi. Kõikide koolijuhtidega tehti intervjuu nende tööruumides ja vestlused kujunesid usalduslikeks, kuid täiesti välistada ei saa sotsiaalselt sobilike vastuste esinemist. On oluline märkida, et andmekogumine sattus aega, mil mitmes Eesti piirkonnas jõudsid avalikkuse ette erimeelsused koolipidaja ja koolijuhtide vahel (Uiboleht, 2019), ning viisil, kuidas neid näiteid toodi välja ka intervjuudes, võis mõista, et koolijuhid näevad haridusvaldkonda ja koolidega toimuvat laiemalt kui vaid oma kooli põhjal.

\section{Andmeanalïïs}

Diktofoniga salvestatud intervjuud on transkribeeritud (kokku 470 lk) sõnasõnalt. Transkribeerimisel kasutati esimeses etapis Alumäe, Tilga ja Asadullah' (2018) loodud automaatse kõnetuvastuse veebipõhist tarkvara ning teises etapis korrigeeriti tekste kuulmise järgi. Kvalitatiivses sisuanalüüsis, mis on tehtud MAXQDA programmi abil, märkis autor tekstides koodidena terviklikud mõtted, kombineerides avatud kodeerimist deduktiivse lähenemisega (Kalmus et al., 2015).

Esimese etapi ehk avatud kodeerimise eesmärk oli jõuda aspektideni, mis koolijuhtide meelest iseloomustavad koolide mainet, ja saada teada, milliste katsumustega on koolid seoses mainekujundusega vastamisi. Tabel 2 toob välja analüüsi tulemusena selgunud peamised teemad, millest nüüdisaegne koolijuhtimine ja kommunikatsioon koolis jäävad tulemuste esitamisel üldiseks taustaks ning kooli maine ja mainekujundus artikli fookusest lähtuvalt põhiosaks.

Tabel 2. Analüüsi tulemusel kujunenud teemad

\begin{tabular}{ll}
\hline Kategooria & Alateemad \\
\hline $\begin{array}{l}\text { Nüüdisaegne } \\
\text { koolijuhtimine }\end{array}$ & $\begin{array}{l}\text { Koolijuhtide tajutud muutunud nõudmised koolidele } \\
\text { Koolijuhtide tajutud nüüdisaja nõudmised koolijuhtidele }\end{array}$ \\
$\begin{array}{l}\text { Kommunikatsioon } \\
\text { koolis }\end{array}$ & $\begin{array}{l}\text { Koolide jaoks olulised huvirühmad ja nende positsioonid direktori hinnangul } \\
\text { Praktiline kommunikatsioon koolis: kes teeb? }\end{array}$ \\
\hline Koolide maine & $\begin{array}{l}\text { Millised indikatorid kõnelevad kooli mainest? } \\
\text { Mis/kes kujundab kooli mainet? }\end{array}$ \\
\hline $\begin{array}{l}\text { Mis mõjutab kooli mainet? } \\
\text { kainekujundus } \\
\text { koolis }\end{array}$ & $\begin{array}{l}\text { Milliseid tegevusi nähakse seoses mainekujundusega? } \\
\text { Millised on mainekujunduse katsumused koolis? }\end{array}$ \\
\hline
\end{tabular}


Teise etapi eesmärk oli paigutada eelkõige koolide mainega ja osaliselt mainekujundusega (tabel 2) seotud koolijuhtide ütlused Helmi (2011) koostatud mainet defineerivate aspektide loogika järgi (tabel 3). Selleks struktureerisin esialgu ringi esimeses etapis leitud koodid ning seejärel töötasin kontrolli eesmärgil materjali läbi lähtuvalt Helmi aspektidest. Nii lisandusid mõned varem märkamata jäänud koodid, mis sobisid täiendama ka esimese etapi avatud kodeerimist. Jaotuse eesmärk oli ühendada eri autorite definitsioonidest lähtuv analüüs praktikute ehk koolijuhtide nimetatud faktoritega.

Tabel 3. Mainet defineerivad aspektid Helmi (2011) analüüsi põhjal

\begin{tabular}{ll} 
Mainet defineeriv aspekt & Aspekti sisuline selgitus \\
\hline Taju aspekt & Huvirühmade üldine hinnang organisatsioonile \\
\hline Ajaline perspektiiv & Mineviku ja oleviku mõju, ootused tulevikule \\
\hline Huvirühmade kuuluvus & Suhete iseloom huvirühmadega \\
\hline Vastastikuse aspekt & Organisatsiooni võimekus ja tahe arvestada huvirühmade ootustega \\
\hline Organisatsiooni tegevus & Organisatsiooni tegevuse järjepidevus \\
\hline Kasulikkus huvirühmadele & Millist kasu näevad huvirühmad organisatsiooni tegevusest endale \\
\hline Konkureeriv aspekt & Võrdlus teiste sama tegevusala organisatsioonidega \\
\hline
\end{tabular}

Tulemuste tõlgendamisel on oluline mõista kvalitatiivsest uuringust tulenevaid piiranguid ehk intervjueeritud juhtide öeldut ei saa üldistada kõikidele koolidele (Kalmus et al., 2015), kuigi lähtuvalt aastatepikkusest kogemusest selgitasid direktorid teemat laiemalt kui üksnes oma kooli piires. Kvalitatiivsele uuringule iseloomulikult ei ole analüüsi juures peetud oluliseks konkreetsete arvamuste hulka (Kalmus et al., 2015), vaid pigem mõtete variatiivsust, kuid mõne hulgale viitava omadussõna kasutamine ilmestab seisukohtade proportsioone valimis.

Valitud uurimismetoodikast lähtuvalt on tulemused ja diskussioon esitatud koos, sest üks osa tulemustest on deduktiivse lähenemise tõttu kohe teoreetilisest raamistikust lähtuva analüüsi aspektidega kõrvutatud ning temaatiliste uurimuste vähesuse tõttu on üldisi kommunikatsiooniarusaamu koolides lihtsam selgitada teoreetilise tausta valguses. 


\section{Tulemused ja diskussioon}

\section{Üldised arusaamad ja mainekujundusega seotud taust koolides}

Kuigi nüüdisaegselt koolijuhilt nõutakse varasemast enam kursisolekut eri valdkondadega (OECD, 2009; OECD, 2014), sealhulgas üldisi juhtimispädevusi (Harris et al., 2003), ei ole realistlik oodata, et koolijuhid saavutaks kõiges täieliku professionaalsuse ja teoreetiliste teadmiste täpsuse. Kõik uuringus osalenud koolijuhid kinnitasid, et nõuded ja ootused nii neile kui ka koolidele üldiselt on ajas muutunud, ehkki neid ootusi tajusid juhid erinevalt. Laias plaanis kirjeldati direktori kohustustena majandustegevust (eelarve, ehitus, inventari soetamine, palgad), pedagoogilist tööd (kuigi põhikoormus õppealajuhtidel), personalitööd ning sise- ja väliskommunikatsiooniga tegelemist (sh esinduskohustust). Olgugi et peamised muudatused puudutasid pigem nimetatud ülesannete proportsioonide teisenemist ajas, tunnistas enamik koolijuhte, et nad kõigega vajalikul määral tegeleda ei jõua ning pidev prioriteetide seadmine on nende töös igapäevane katsumus. Leiti, et kooli kommunikatsiooniga (sh mainekujundusega) teadlikumat tegelemist võivad varjutada nii suured aktuaalsemad tegevused (koolimaja ehitus; kohaliku hariduselu ümberkorraldamine), igapäevased kiiret lahendust vajavad probleemid kui ka mõnel juhul oskuste ja teatud isikuomaduste puudumine (esinemiskindlus, kirjutamis- ja märkamisoskus).

Kommunikatsiooni osatähtsuse suurenemist on mõned autorid põhjendanud koolide suhtes kasvava avaliku huviga (Breiter \& Ruhe, 2018; Isaksson \& Enbom, 2015) ja muutunud meediakeskkonnaga (Breiter \& Ruhe, 2018), kuid direktorid tunnetasid olukorda pisut erinevalt ja kohati suisa vastandlikult. Näiteks erinesid arvamused selles, kas nüüdisaegsel koolil on vaja end väljapoole näidata:

Et mulle tegelikult meeldiks ilmselt koolis tö̈tada rohkem siis, kui ma saaksin tegeleda nende protsessidega, mis puudutab seda kooliperet konkreetselt, mitte selle turundusliku ja müügipoolega, aga ühiskond nõuab seda. Ühiskond tahab täpselt teada, mis koolis sünnib. Kui nad seda ei tea, siis nad arvavad, et kool on halb, koolis ei toimugi midagi, mis on kõige veidram selle asja juures. (KJ_11)

Nü̈̈d, kui vaadata nagu seda põhimõtet, et miks kooli direktor peaks oma kooli nagu promoma, siis see on, see oli jäänud tugevasti eelmisesse kümnendisse. Ehk siis oli nagu teadmine, et meil on olemas eliitkoolid ja siis on olemas tavakoolid /.../ ei pea ennast promoma, sest tegevus toimub maksumaksja rahast. (KJ_12) 
Enamjaolt olid intervjueeritud juhid seda meelt, et tänapäevane kool on avatum ja uueaegsete meediakeskkondade kasutamine (e-kool, Studium, koduleht, Facebook, e-kirjad) loomulik viis huvirühmadega (sh avalikkusega) suhtlemiseks. Ka koolide jaoks n-ö klassikaliste huvirühmade ehk õpilaste, lastevanemate, õpetajate-koolitöötajate ja koolipidaja (Breiter \& Ruhe, 2018; Skallerud, 2011) rolli tähtsustamises olid direktorid üldiselt ühisel arvamusel. Nimetatud huvirühmade kõrval nägid aga koolijuhid veel tervet hulka (eelkõige) väliseid huvirühmi, kes on mingil moel kooliga seotud ja kelle hoiakud kooli suhtes kooli tegevust mõjutavad. Kuigi nende huvirühmade hulgas olid näiteks teised koolid, teised organisatsioonid, HTM, lasteaiad, kogukond, olenes nende positsioon ja olulisus kooli eesmärkidest. Märkimisväärne oli see, kui erinevad on tavad suhtlemisel vilistlaste kui huvirühmaga. Sealjuures võis küll leida viiteid, et kujunenud koostöökultuur sõltub ka vilistlaste hulgas kujunenud aktiivsema juhtrühma initsiatiivist, mitte ainult kooli püüdlustest.

On mõistetav ja igati aktsepteeritav, et koolid seavad oma prioriteedid ja neist lähtuvad huvirühmadega seotud tegevused. Teisalt võis mõista, et paljud nüüdisaegsed praktikad, nagu huvirühmade kaasamine kooli juhtimisse (Kukemelk \& Ginter, 2016), väliste ressursside igakülgne kasutamine kooli arenguks, püüdlus kujuneda laiemalt haridusvaldkonna juhiks (Fullan, 2014), olid uuringusse kaasatud koolides rakendatud väga erineval tasemel ja põhjuseid võis näha koolikultuuri olemuses, ajapuuduses, individuaalsetes töömeetodites ja hoiakutes.

Pöördudes tagasi esitatud tsitaatide juurde, võib märgata mõisteid turundus ja promo, mis käisid läbi pea igast intervjuust, olgugi et mõnel korral tunnistati, et koolide kontekstis on need mõisted pisut kohatud, sest seonduvad pigem äriloogikaga. Samas kontekstis räägiti ka konkureerimisest ja kuigi koolijuhid jäid teiste koolide suhtes solidaarseks, tunnistati vahel, et „vaatamata ilusale jutule koostöö olulisusest on ikkagi kohalikul tasandil koolid konkurendid“ (KJ_14), mida on täheldanud ka mõned autorid (nt Bunar \& Ambrose, 2016; Isaksson \& Enbom, 2015). Vaid paari direktori meelest ei olnud ühtlushariduse kontekstis konkureerimine või koolide endi esiletõstmine kuidagi õigustatud või vajalik, mis ei tähenda, et nad oleks eitanud koolidevahelist konkurentsiolukorda. Seega nähtub intervjuudest, et ehkki nüüdisaegse koolijuhtimise juures tajuti new public management'i (NPM) jooni (Türk et al., 2011), ei ole seda lähenemist praktikas täielikult omaks võetud ning äriloogika (kohati sunnitud) lõimimine võib koolijuhtides tekitada vastuseisu.

Võib täheldada, et uuringus osalenud koolijuhid tajusid vastutust kaasas käia nüüdisaja nõuetega, kirjeldasid kommunikatsiooni tänapäevaste kanalite kaudu ja üldiselt on teinud kindlaks koolile olulisemad huvirühmad. Mis puutub koolijuhtide hoiakutesse, siis need ei tundunud sõltuvat ei kooli 
asukohast, suurusest ega õppeastmete hulgast, vaid olid pigem kombinatsioon personaalsetest tõekspidamistest, kogukondlikust kultuurist (juht peab vastama kogukonna ootustele) ja praktilistest kogemustest.

\section{Kooli mainet loovad aspektid}

Intervjuude käigus ei palutud teadlikult direktoritel mainet defineerida, sest eesmärk oli koguda koolijuhtide professionaalse kogemusega seotult tajutud ja teadaolevaid aspekte, mitte veenduda nende teoreetilistes teadmistes ja termini sõnastamise osavuses. Siiski kumas intervjueeritavate jutust läbi maine seotus kooli kui organisatsiooni identiteediga (sh visuaalse), huvirühmade vaatenurkadega ning koolitöötajate individuaalse ja kollektiivse käitumisega. Tuginedes maine definitsioone analüüsinud autoritele (nt Brown et al., 2006; da Camara, 2011; Helm, 2011), saab seega olla kindel, et uuringus osalenud koolijuhid tajusid oma varasematest teadmistest või sisetundest lähtudes maine olemust üsna sarnaselt eelmistes uuringutes rakendatud kontseptsioonidega.

Maine mõiste selgitamisel püüdsid koolijuhid tõlgendada ka oma kooli kuvandit ehk Browni jt (2006) parafraseerides vastata küsimusele „Mida koolijuhid usuvad, et koolist arvatakse?". Kuigi osa uuringus osalenud koolijuhtidest tõdes, et mainet peaks hindama eri vaatenurkadest ning on huvirühmi, kelle meelest võib kooli maine olla kehvem, siis üldiselt usuti, et n-ö konkurentsipiirkonnas on nende kool pigem keskmisest parema või hea mainega. Vaid üks direktor pidas võimalikuks, et kooli maine on keskmisest allpool. Samuti mainiti hea või halvema maine kujunemises rolli keeruliselt analüüsitaval faktoril see müstiline miski (KJ_3). Kahtlemata oli juhtide meelest kõige olulisem, et kooliga tihedamalt seotud huvirühmad mõistaks nende püüdlusi ja oleks rahul; siis pole kaugemate sihtrühmade arvamusel arvestatavat mõju. Mitmel juhul peeti kõige olulisemaks teha võimalikult hästi igapäevatööd.

Me peame tegema oma asju, mitte kuskile pjedestaalile trügima, aga et kui keegi tahab meie aknast sisse vaadata, et siis see, mis paistaks, oleks ilus, et aga meie enda pärast ilus, mitte selle pärast, kes vaatab. (KJ_6)

Kuigi eelnev on olnud koolikonteksti mõistmiseks oluline taust, on selle uuringu puhul väärtuslikuks tulemuseks teadmine, millised indikaatorid annavad pildi kooli mainest, sest ühelt poolt selgitavad need aspektid maine tajumist, mitte üksnes ei kirjelda, ning teiselt poolt ei saa koolid mainekujundusega tegeleda, kui pole teada, milliseid faktoreid seejuures hindama peaks (Skallerud, 2011). Nagu mainitud, võimaldab Helmi (2011) koostatud maine eri aspektidest inspireeritud jaotus (tabel 4) ühendada maineuuringute teooria ja koolijuhtimise praktikatest lähtuvad mõtted. Tabelis toodud indikaatorid on väljavõtted 
intervjuudest ja toimetatud vaid selge mõtte vormistamiseks või sarnaste mõtete koondamiseks.

Kindlasti on oluline märkida, et osa indikaatoritest sobituks mitme alateema alla ja tabelis olev jaotus pole seega ainuvõimalik. Samuti võib täheldada, et kuigi suurem osa näitajatest võivad kehtida pea kõikide koolide kohta, pole neile sobivad mõõdikud alati universaalsed ning sõltuvad kooli töömeetoditest, eripäradest ja eesmärkidest. Lisaks ei käi kõik toodud punktid ühtselt kõikide koolitüüpide kohta (kogukonnakool vs. laiem vastuvõtt; konkurents maal vs. linnas; põhikool $v s$. gümnaasium) ning võimalik, et mõne kooli unikaalsusest sõltuvaid indikaatoreid saaks veel lisada.

Koolijuhtide arvamuste hulgast ja näitajate sisulisest variatiivsusest nähtub, et kooli maine on pea kõikehõlmav. Intervjuudes leidsid mainimist nii avalikus diskussioonis käsitletud faktorid, nagu korras koolihoone, head akadeemilised tulemused, töötajate väärtustamine ja edukad vilistlased (Aljas, 2013; Heinaru, 2016; Kasemägi, 2018; Kukin, 2018; Salu, 2018), kui ka SA Innove rahuloluküsitluse indikaatorid, nagu üldine rahulolu, uhkusetunne ja n-ö soovitamisjulgus (Lukk et al., 2016). Samas näitab punktide rohkus selgelt, kui väikese osa tervikust moodustab levinud, kuid probleemne koolide reastamine riigieksamite tabelite järgi (Heinaru, 2016; Sutrop et al., 2017). Liiati tõid ka direktorid välja, et riigieksami tulemused näitavad vaid ühe konkreetse lennu akadeemilist võimekust mõnes õppeaines. Samuti ei puuduta see kriteerium põhikoole, mille puhul saab kooli mainest siiski rääkida.

Tabel 4. Koolijuhtide praktikatest lähtuvad mõtted Helmi (2011) mainet defineerivate aspektide süsteemis

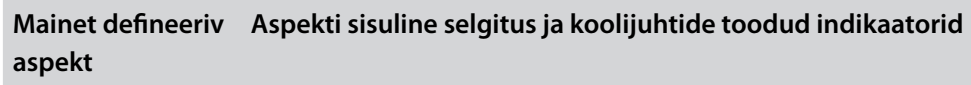

$\begin{array}{ll}\text { Ajaline } & \text { Mineviku ja oleviku mõju, ootused tulevikule } \\ \text { perspektiiv } & \text { Vilistlased toovad oma lapsed samasse kooli } \\ & \text { Oma vilistlased tulevad õpetajaks } \\ & \text { Kooli (vana) lugu, ajalugu (uueaegses käsitluses ka nn edulood) } \\ & \text { Kogukonna ajalooline mälu (pigem väikestes kohtades, koduküla patriotism) } \\ & \text { Visiooni turundamine; tulevikuvaade (eelkõige nullkoolide; uute koolide teema) } \\ & \text { Esimene seos, mida kooli kohta kuuldud või teatakse } \\ & \text { Vilistlaste arvamus mõni aastat pärast lõpetamist }\end{array}$




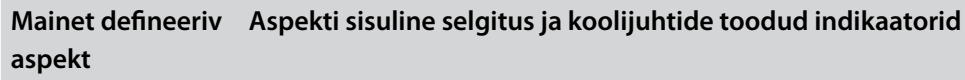

Huvirühmade kuuluvus

Kahepoolse suhte aspekt

Organisatsiooni tegevus

\section{Suhete iseloom huvirühmadega}

Kas lapsevanemad tulevad kooli (koosolekud, üritused jm)

Milliseid huvirühmi peetakse koolis oluliseks ja kuhu nad positsioneeritakse Suhted koolipidajaga

Side kogukonnaga ja kui palju kaasatakse õpilasi kogukonna üritustele

\section{Kooli võimekus ja tahe arvestada huvirühmade ootustega}

Kuidas õpetaja end koolis tunneb (personali voolavus; sisekliima; väärtustamine)

Kas lapsed on õnnelikud (ka õpilaste arvu muutused)

Kas lapsed tahavad öelda, et esindavad just oma kooli

Head võimalused erivajadustega lastele

Rahuloluküsitlused; kooli enda loodud, Innove uuringu tagasiside Kooli füüsiline seisukord (renoveerimine tõi suurema huvi)

Kooli turvalisus (füüsiline ja emotsionaalne)

Kooli esmamulje: sekretär, administraator, turvamees

Vähesed kaebused kooli kohta

Väljastpoolt tulnud tänu, kiitus, tunnustus; positiivsed meediakajastused

\section{Kooli tegevuse järjepidevus}

Traditsioonid

Üritused (hästi korraldatud, silmapaistvad)

Sümboolika (koolivorm, logo, lipp, laul)

Osalemine algatustes ja projektides (tegevuse nähtavakstegemine)

(Kooli arenguks oluliste) koostööpakkumiste hulk, koostööpartnerite arv Koolijuhi ja õpetajate professionaalsus (oskus suhelda; korrektne käitumine) Mõningane konservatiivsus (hariduse üldteada tavad ja toimimine) Statistilised näitajad (Haridussilm)

Hästi töötavad ja põhjendatud lahendused kooli juhtimises (strateegia)

Kui palju tuntakse huvi kooli tegevuse vastu (teised koolid, ajakirjandus)

$\begin{array}{ll}\text { Kasulikkus } & \text { Millist kasu kooli tegevusest huvirühmad endale näevad } \\ \text { huvirühmadele } & \text { Tugev õppetöö, laste õppeedukus, tasemetööd } \\ & \text { Kvalifikatsiooniga õpetajad } \\ & \text { Gümnaasiumide lisandväärtuse näitaja (Innove) } \\ & \text { Huviringide jm võimaluste hulk (muusikakool, spordivõimalused) } \\ & \text { Kuhu kooli õpilased hiljem sisse saavad (kas nn eliitkooli ka) } \\ & \text { Minimaalne hulk väljalangejaid } \\ & \text { Kas 9. klassi lõpetajad tahavad jääda gümnaasiumisse (tugevamad õpilased) } \\ \text { Konkureerimine } & \text { Võrdlus teiste (sarnaste) koolidega } \\ & \text { Riigieksamite edetabelid } \\ & \text { Õpilaste tulemused olümpiaadidel ja võistlustel } \\ & \text { Õpilaste arv } \\ & \text { Kooli sisseastujate arv (kas tekib konkurss kohtadele) } \\ & \text { Millise kooli vilistlased maksavad kõige enam makse riigile } \\ \text { (Positiivselt) tuntud vilistlased }\end{array}$


Tabelile saab veel ühe indikaatorina lisada koolist osaliselt sõltumatu kohaliku piirkonna ja kogukonna maine. Direktorid tõid välja vähem maineka linnaosa, „kolka“ või ajalooliselt konkureeriva (küla)kogukonna põhjustatud hoiakute mõju koolile ehk siis Helmi (2011) lähenemisest lähtuvalt on võimalikel huvirühmadel piirkonna puuduste tõttu raske näha neile pakutavat kasutegurit ka koolilt. Samas kirjeldasid intervjueeritavad paari olukorda, kus kooli väga hea töö on aidanud ka piirkonna mainet tõsta.

Vaadeldes ka võimalikku negatiivse maine kujunemist või analüüsides teoreetiliselt nn halva mainega kooli olukorda, oskasid pea kõik koolijuhid nimetada vähemalt üht juhtumit (koolijuhi või õpetaja käitumine; kommunikatsiooniprobleem; vanema rahulolematus; koolipidaja käitumine), kus kool on saanud negatiivset tähelepanu, mis omakorda on mõjutanud kooli kuvandit. Seejuures võis täheldada, et negatiivse märgi (sh juhi või mõne õpetaja individuaalse kuvandi) mõju kirjeldati rühmade perspektiivi asemel kohati hoopis personaalsena. Nõrgemalt seotud isikute jaoks võis negatiivne info olla üks kiirelt mööduv infoühik, aga võis olla ka ainus ja määrav aspekt, mida üldse kooli kohta teatakse. Lähemalt seotud isikute jaoks võis olla isikliku kasu kadumine piisavalt suur, et otsustati kooli vahetada, või siis vastukaaluks tugevnes meie-tunne ja toetus koolile, sest „omad teavad paremini, kuidas asjad on“. Direktorite jutu põhjal võis eeldada, et kui probleemsed juhtumid on üksikjuhtumid, mis jäävad kooli tugeva identiteedi ja väärtuste varju ja maandatakse oskusliku suhtlemisega, on negatiivse info mõju hiljem tuntavalt väiksem. Seega kui kool oma üldise oleku ja suhtlemisega veenab huvirühmi, et suudab ja tahab endist viisi vastata nende ootustele, mis on oluline aspekt Helmi (2011) analüüsis, ei pruugi negatiivne üksikjuhtum pikemas perspektiivis mainet rikkuda.

Kooli hea maine varjuküljeks oli aga mõne direktori sõnul kaasnev vastutus ja ootuste kasv. Kooli mainekujundust saab seega vaadelda omamoodi spiraalina, kus täidetud eesmärgid kinnitavad tegevuse vastavust ootustele ehk hoiavad ja parandavad mainet (Vaarik, 2014), kuid põhjustavad omakorda uute ootuste tekke.

... ja ka nende (eelkõige lapsevanemate) ootused selle pärast nagu tõusevad, et kui me täna teeme hõbedast asju, siis homme peaks nü̈̈d juba kullast olema, ülejärgmine aasta kindlasti võiksid need olla mingisugustest veel kallimatest materjalidest, et nende ootused nagu kasvavad pidevalt ka selle turundusprotsessi käigus, sest ka nende nägemus areneb, nende kogemus areneb. (KJ_11)

Pealtnäha vastukäivat seisukohta väljendas üks direktor aga ootamatu paralleeli abil: 
... tegelikkuses ei ole nagu koolidel sellist asja nagu maine, et kool on óppimise koht. Mine ja õpi! Nii nagu vangla mainet ei ole tegelikult olemas, et ma istun praegu mainekas vanglas. Kui sa istud seal, siis noh, miks pandi? See, mis su elu mõte seal jube mainekas vanglas istumine? (KJ_12)

Hoolimata veidi küsitavast metafoorikasutusest seisnes toodud arvamuse taga idee võimalikult ühtse kvaliteediga haridusest, mis on ka HTM üks eesmärkidest (HTM, i.a), ja mis sobitus Fullani (2014) ideega, et süsteem peaks arendama meisterlikkust kõikides oma koolides. Kahtlemata seda püütakse teha koolituste, uuringuraportite (näiteks Innove rahuloluküsitlused) ja algatuste kaudu, kuid samas võib mainekujunduse kontekstis näha erinevusi koolijuhtide seisukohtades ja koolide vajadustes.

\section{Praktikad ja väljakutsed koolide mainekujunduses}

Kuigi suurem osa intervjueeritud juhtidest andis mõista, et mainekujundus pole nende planeeritud tegevustes eesmärk omaette, kirjeldati maine hoidmist (ja parandamist) tähtsa taustana kooli igapäevaelus (nt sisekorraeeskirjadena; üldistes kokkulepitud väärtustes) ja valitud käitumisviisides. Mõnel juhul tõid direktorid välja spetsiaalselt mainekujunduseks tehtud samme, milleks olid näiteks avatud uste päeva korraldamine, uue õppesuuna planeerimine ja reklaam, avalikud esinemised ja koostöö kohaliku omavalitsuse ehk koolipidaja avalike suhete spetsialistiga. Sage koolijuhtide seas levinud hoiak oli küll, et spetsiaalselt peaks mainekujundust tegema koolid, kus on midagi kehvasti, uued koolid, kes peavad oma lugu looma, või kindla kallakuga koolid. Samuti pole suurem avalik tähelepanu ehk niivõrd oluline väikese maakooli jaoks, sest alternatiiv üldiselt puudub.

Üks koolijuht tunnistas, et kuigi nad on kooli ajaloos teadlikult püüdnud endale tähelepanu tõmmata, on sellest aja jooksul loobutud, et üha enam väärtustada tugevat sisulist tööd. Nii saab lisaks sisemisele rahulolule kujuneda ka hea maine, sest iga tegevus ise on juba kommunikatsioon, nagu on viidanud ka Vaarik (2014).

Ma arvan ta siiski algab sellest, et meile endale nii meeldib, et me ei tee seda nagu vastu tahtmist, et olla nagu mainekujunduslikult kuidagi kunstlik ja meile meeldib täpselt selline tegevus /---/Et me nagu ise ajame mingeid ideaale taga. /---/ Meil on inimesed, neile meeldib teha; /---/ Ja [maine] hakkab sellest peale, et me ise tahame teha asju kvaliteetselt või kuidagi ise suure rõómu ja naudinguga. (KJ_4)

Seda, et mainekujundus pole midagi, mida peaks eraldi tegema, väljendasid pea kõik koolijuhid ja üks neist võttis selle seisukoha tabavalt kokku. 
Vot meil niimoodi pole sõnastanud, et me hakkame nü̈̈d kooli mainet spetsiaalselt kujundama. Ma ei ole koolijuhina selle järgi kunagi niimoodi mõelnud või osanud mõelda, et see on umbes nagu ma lähen nüüd õnne otsima. Et ma lähen nüüd hakkan, ma teen seda kooli mainet. Kui me teeme õigeid asju, mida me ise õigeks peame. Ja mida me näeme, et ka lapsevanemad ja hoolekogu ootavad, siis selle najal see kooli maine kujunebki. (KJ_19)

Eeltoodust nähtub, et mitme autori tähtsustatud huvirühmade rolli mainekujunduses (nt Gilpin 2010; Moss \& DeSanto, 2011) tajusid ka intervjueeritud koolijuhid koolikeskkonnas. Samas võis täheldada, et peale suhteliselt passiivse (ootuste väljendaja) rolli omistati huvirühmadele või nende esindajatele ka aktiivset rolli koolide mainekujunduses.

Lapsevanem on ju üks peamine mainekujundaja. Lapsevanem on see, kes ei ole seotud selle piiranguga, mis on kooli kokkulepe, et see on meie kool. /---/ Seda, mida sa töötajatega teha, sõlmida sellised nagu lepped, eks ole. Mida sa saad lastele sisendada? Seda, et su sinu kool ja seda paremini sinust arvatakse, mida paremini sa oma koolist rä̈gid ja käitud. Nii. Aga vanem ei ole sellega piiratud... (KJ_2)

Lastevanemaid ja ka vilistlasi individuaalsel tasandil mainisid mõned koolijuhid lähtuvalt nende professionaalsetest oskustest, kuid see oli pigem arvesse võetud ühe võimalusena, kui peaks vajadus tekkima, mitte tavapraktikana. Kooli sees nägid direktorid kooli maine eest peamise vastutajana ennast, kuigi oluline roll oli kanda teistel koolitöötajatel ja õpilastel.

Kes on lastevanemate silmis kooli mainekujundaja number üks? Klassijuhataja. Ja klassijuhataja peab oskama seda teha. Ja meie, kooli juhtkonna asi on neid aidata sel teel. (KJ_18)

Mainekujunduse ja üldisemalt kommunikatsioonivaldkonna ülesannete jagamisel oli üks läbivaid näitajaid töötajate individuaalsed omadused ja vähem mängis rolli ametikoht koolis. Nii võisid koolijuhi kõrval neid ülesandeid täita õppealajuhataja, huvijuht, arendusjuht, projektijuht, kommunikatsioonijuht (erandlik, enamasti puuduvad vahendid spetsialisti palkamiseks) ja mõni õpetaja. Huvitav on asjaolu, et sageli nähti kommunikatsioonipädevusi pigem isikuomadustena stiilis „ta on meil selline inimene“. Intervjuudest lähtuvalt sai eristada esinejaid, kirjutajaid, sotsiaalmeedia tundjaid, korraldajaid ja rahustajaid (leiavad keerulistes olukordades õiged sõnad). Mitu juhti andis mõista, et erinevate oskustega töötajaid on kaasatud lisaks ajapuudusest lähtuvale vajadusele ka juhi enda puudujääkide kompenseerimiseks.

Koolide mainekujunduse olulise eeldusena kirjeldas suur osa juhtidest head sisekommunikatsiooni ehk seda, kuidas kujundatakse ühtset väärtusruumi ja tegutsemispõhimõtteid. Ühe katsumusena mainiti siin eri põlvkonna 
ja erinevate hoiakutega õpetajatele kaasaegse muutunud meediakanalite ja kommunikatsiooniviiside vajalikkuse (Porterfield \& Carnes, 2012; Watson, 2012) selgitamist.

Samuti keerulise, kuid samas mainekujunduses vajaliku poolena tõid pea kõik intervjueeritud koolijuhid välja meedia ja ajakirjanikud. Pea kõikidele koolidele oli oluline saada positiivset meediakajastust, kuid teisalt viidati juurdunud arusaamale (eriti õpetajate hulgas), et ajakirjanikud on huvitatud ainult negatiivsetest uudistest ja seetõttu ollakse nende suhtes vähem või rohkem umbusklikud. Ajakirjanikega suhtlemist nimetati peamiselt direktorite ülesandena ja kui kriitiliste teemadega tegelevad koolides igal juhul koolijuhid, siis ka positiivsed kontaktid meediaga eeldasid üldiselt juhi teavitamist. Kirjeldatud usaldamatus ja kohatine hirm näivad olema seotud teatud võimupositsioonidega, kus ajakirjanikud kui vahendajad saavad mõjutada avalikku arvamust (Rawolle, 2010) ja koolil puudub enamjaolt võimalus avaldatavat kontrollida.

Intervjuude põhjal võis arvata, et koolide tahe vastata oma huvirühmade ootustele (Helm, 2011) on sageli suurem kui võimalused selleks. Nii on võimalik koolijuhtidega tehtud intervjuudest leida ka kooli mainekujunduse kitsaskohad, mida saab vaadelda kui efektiivsemat tööd piiravaid tegureid. Tabel 5 jaotab kitsaskohad lähtuvalt direktorite kirjeldatud asjaoludest, kuigi olgu siinkohal öeldud, et mitmed tegurid on omavahel seotud ja neid saab kohati lahendada poolte koostöös.

Tabel 5. Efektiivsemat mainekujundust takistavad tegurid

\begin{tabular}{|c|c|c|}
\hline Väline tegur & b) & $\begin{array}{l}\text { Piirkonna maine, kogukonna hoiakud ja kohalik poliitika mõjutavad } \\
\text { suhtumist kooli } \\
\text { Meedia, ka sotsiaalmeedia toimimise mõistmine on keerukas; puudub } \\
\text { tegelik kontroll meedia üle }\end{array}$ \\
\hline $\begin{array}{l}\text { Koolisüsteemi } \\
\text { eripäradest } \\
\text { sõltuv tegur }\end{array}$ & c) & $\begin{array}{l}\text { Sisuline töö vajab pühendumist ja aega (sh ajamahukas erivajadustega } \\
\text { õpilaste hulga suurenemine); vähem ajaressurssi täiendavateks } \\
\text { ülesanneteks } \\
\text { Peamine huvirühm ehk lastevanemad on väga heterogeenne - } \\
\text { keeruline vastata kõikidele ootustele } \\
\text { Negatiivne kajastus ei ole kuidagi hea, sest võib koolile külge jääda } \\
\text { aastateks }\end{array}$ \\
\hline $\begin{array}{l}\text { Osaliselt süsteemist, } \\
\text { osaliselt juhist } \\
\text { sõltuv (oleneb kooli } \\
\text { eelarvest ja kultuurist) }\end{array}$ & a) & $\begin{array}{l}\text { Oluline leida tasakaal ühtsete hariduslike eesmärkide (riigi ja süsteemi } \\
\text { vajadus) ja oma kooli eripärade tutvustamisel } \\
\text { Eelarves puudub raha eraldi spetsialisti palkamiseks või teenuse } \\
\text { kasutamiseks }\end{array}$ \\
\hline $\begin{array}{l}\text { Koolist või juhist } \\
\text { sõltuv tegur }\end{array}$ & $\begin{array}{l}\text { a) } \\
\text { b) }\end{array}$ & $\begin{array}{l}\text { Kooli ühised või juhi individuaalsed eesmärgid, prioriteedid ja hoiakud } \\
\text { Harjumused, mida on raske muuta. Eelkõige meeskonna sees näiteks } \\
\text { õpetajad, kellele avalik tähelepanu pole mugav ega omane } \\
\text { Puuduvad professionaalsed oskused ja sageli pole kelleltki abi küsida }\end{array}$ \\
\hline
\end{tabular}


Kokkuvõtlikult saab öelda, et kõigi intervjueeritud direktorite tegevuses oli olulisel kohal Browni jt (2006) esitatud küsimus „Mida me tahame, et organisatsioonist arvatakse?". Samas tunnistasid direktorid, et vahendeid ja oskusi kooli maine teadlikumaks kujundamiseks pole neil alati piisavalt ning mõned katsumused võivad olla seotud hoopis kooliväliste teguritega.

\section{Kokkuvõte}

Kuna koolide maine on koolide ja nende huvirühmade jaoks tähtis, on kindlasti vaja teemat edasi uurida ja arendada võimaluse korral avalikku diskussiooni, et ühtlustada arusaama niivõrd subjektiivsest mõistest. Kooli maine ei ole konstantne väärtus, vaid sõltub üldiselt pikemast ajalisest faktorist ja maine tajuja positsioonist huvirühmade koosseisus.

Koolide maine võrdlemine või järjestamine ei pruugi olla õigustatud isegi väga sarnase profiiliga koolide kontekstis, sest see sõltub otseselt kooli enesemääratlusest, eesmärkidest ja unikaalsest huvirühmade rolli hindamisest. Kui üldiselt võivad koolide maine puhul kehtida universaalsed tõekspidamised ja teoreetilised definitsioonid, on professionaalsemal mainekujundusel koolides hulk piiranguid, mis seisnevad näiteks põhitegevuse ajamahukuses, olulise huvirühma (vanemate) heterogeensuses, limiteeritud eelarves ja oskuste erinevas tasemes.

Praktikas võiks toodud indikaatoreid (tabel 4) vaadelda abistava materjalina kooli maine analüüsimisel ja ehk ka kooli rahuloluküsitluste täiendamisel. Lisaks võivad indikaatorid olla inspiratsiooniks, et leida positiivseid aspekte, millega kooli esile tõsta ja avalikkuses kajastada. Lähtuvalt toodud indikaatorite paljususest võib näha, et kooli mainekujunduses võivad mõju omada ka esmapilgul seostamatud otsused ja ette võetud sammud. See tähendab, et mainekujundust ei saa piiritleda ainuüksi konkreetse ürituse või väljapoole suunatud (reklaam)tegevuse korraldamisega. Samal moel võiks läheneda kommunikatsiooni ja mainekujundusega seotud terminitele (turundus, promo) sisulisemalt, et mõista nende universaalset olemust ja näha kaugemale kommertsloogikast.

Maine mõõdetavuse juurde jääb paratamatult tajutavaid aspekte, mida on keeruline mõõta või skaaladele seada, kuid ei ole kohane väita, et need on n-ö mõjutamatud ja neid ei saa muuta. Nagu intervjuudest nähtus, on maine tunnetamise juures olulisel kohal ka head emotsioonid (õnnelikkus ja rahulolu). Kui oma tegevusi planeerides arvestada huvirühmade ootusi, soove ja vajadusi, on võimalik teadlikult luua kooliga positiivseid seoseid.

Vastates pealkirjas püstitatud küsimusele: kooli maine koosneb kõigest, mida kool teeb, ja ka sellest, mida kool huvirühmade ootuste vastaselt ja põhjendamatult tegemata jätab. Kooli maine hindamisel tuleks aga arvesse võtta kooli 
keskseid eesmärke (õppetööd), olemasolevaid tingimusi (ruume, õpilaste ja töötajate koosseisu, piirkonda) ja eespool mainitud piiravaid tegureid.

\section{Tänusõnad}

Autor on väga tänulik koolijuhtidele aja, usalduse ja inspireerivate intervjuude eest ning retsensentidele ja kolleegidele asjakohaste soovituste eest.

\section{Kasutatud kirjandus}

Aljas, R. (2013, 19. juuni). Halb maine sunnib kooli nime muutma. Eesti Päevaleht, lk 5 .

Alumäe, T., Tilk, O., Asadullah. (2018). Advanced Rich Transcription System for Estonian Speech. Baltic HLT.

Breiter, A., \& Ruhe, A. H. (2018). Paper versus school information management systems: Governing the figurations of mediatized schools in England and Germany. A. Hepp, A. Breiter, U. Hasebrink (Eds.), Communicative Figurations Transforming Communications in Times of Deep Mediatization (pp. 313-339). Palgrave Macmillan: Cham. https://doi.org/10.1007/978-3-319-65584-0_13

Brown, T. J., Dacin, P. A., Pratt, M. G., \& Whetten, D. A. (2006). Identity, intended image, construed image, and reputation: An interdisciplinary framework and suggested terminology. Journal of the academy of marketing science, 34(2), 99-106. https://doi.org/10.1177/0092070305284969

Bunar, N., \& Ambrose, A. (2016). Schools, choice and reputation: Local school markets and the distribution of symbolic capital in segregated cities. Research in Comparative and International Education, 11(1), 34-51. https://doi.org/10.1177/1745499916631064

Bush, T., \& Bell, L. (Eds.). (2002). The principles and practice of educational management. London: Sage.

da Camara, N. Z. (2011). Identity, image and reputation. S. Helm, K. Liehr-Gobbers, \& C. Storck (Eds.), Reputation management (pp. 47-58). Berlin, Heidelberg: Springer. https://doi.org/10.1007/978-3-642-19266-1_6

Fullan, M. (2001). Leading in a Culture of Change. San Francisco: Jossey-Bass.

Fullan, M. (2014). Koolijuhi kolm võtmetegurit mõjusaks juhtimiseks. Tartu: Atlex.

Gilpin, D. (2010). Organizational image construction in a fragmented online. media environment. Journal of Public Relations Research, 22(3), 265-287 https://doi.org/10.1080/10627261003614393

Haridus- ja Teadusministeerium. (2014). Riigigümnaasiumide kvaliteedikokkulepe. Külastatud aadressil http://www.hm.ee/index.php?popup=download\&id=12611

Harris, A., Day, C., Hadfield, M., Hopkins, D., Hargreaves, A., \& Chapman, C. (2003). Effective leadership for school improvement. London: RoutledgeFalmer.

Hatzopoulos, P., Kollias, A., \& Kikis-Papadakis, K. (2015). Võrdseid võimalusi ja óppimist soodustav koolijuhtimine ning koolide autonoomia. Eesti Haridusteaduste Ajakiri, 3(1), 50-64. https://doi.org/10.12697/eha.2015.3.1.03 
Heinaru, R. (2016, 7. okt). Millest sõltuvad kooli tulemused ja maine? Õpetajate leht. Külastatud aadressil https://opleht.ee/2016/10/millest-soltuvad-kooli-tulemusedja-maine/

Helm, S. (2011). Corporate reputation: an introduction to a complex construct. S. Helm, K. Liehr-Gobbers, \& C. Storck (Eds.), Reputation management (pp. 3-16). Berlin, Heidelberg: Springer. https://doi.org/10.1007/978-3-642-19266-1_1 Innove. (2016). Haridusasutuse juhi kompetentsimudel.

Innove. Opetajaameti mainekujundus. Külastatud aadressil https://www.innove.ee/ opetaja-ja-koolijuhi-areng/okpat/opetajaameti-mainekujundus/

Isaksson, J., \& Enbom, J. (2015). News Management in the Swedish School Sector. International Conference on Management, Leadership \& Governance (pp. 127133).

Ishaq, K., \& Kritsonis, W. A. (2009). School leadership makes a difference: A sociological perspective of effective strategic planning and integrating realms of meaning into school improvement. National Forum of Applied Educational Research Journal, 23(1-2).

Kalmus, V. Masso, A., \& Linno, M. (2015). Kvalitatiivne sisuanalüüs. K. Rootalu, V. Kalmus, A. Masso, ja T. Vihalemm (toim), Sotsiaalse analüüsi meetodite ja metodoloogia õpibaas. Külastatud aadressil http://samm.ut.ee/kvalitatiivne-sisuanalyys

Kasemägi, K. (2018, 30. sept). Kaspar Kasemägi: kust see kooli „maine“ tuleb? Tartu Postimees. Külastatud aadressil https://tartu.postimees.ee/6417654/kaspar-kasemagi-kust-see-kooli-maine-tuleb

Kessa, S. (2013). Kooli valikut mõjutavad tegurid ja valikute seos muutustega piirkonna hariduskorralduses (Viljandi koostööpiirkonna näitel). Magistritöö. Tartu Ülikool. Sotsiaal- ja haridusteaduskond.

Koschmann, M. A. (2012). Developing a communicative theory of the nonprofit. Management Communication Quarterly, 26(1), 139-146. https://doi.org/10.1177/0893318911423640

Kukemelk, H., \& Ginter, J. (2016). Estonia: School leadership in Estonia 2001-2013: H. Ärlestig, C. Day, \& O. Johansson (Eds), A Decade of Research on School Principals. Cases from 24 Countries (pp. 125-135). Switzerland: Springer. https://doi.org/10.1007/978-3-319-23027-6_7

Kukin, K. (2018, 18. sept). Variku kool loodab uuendustega mainet parandada. Tartu Postimees.

Kuurme, T. (2007). Eesti kool 21. sajandi algul: kool kui arengukeskkond ja õpilase toimetulek. Tallinn: Tallinna Ülikooli kirjastus.

Lagerspetz, M. (2017). Ühiskonna uurimise meetodid: Sissejuhatus ja väljajuhatus. TLÜ Kirjastus.

Lukk, M., Sammul, M., Tamm, A., Leijen, Ä., Adov, L., Aksen, M., \& Themas, A. (2016). Kontseptsioon ja mõotevahendid hindamaks rahulolu üld-, kutse- ja kõrgharidusega ning täiendusõppe võimalustega. Tartu: Tartu Ülikool.

Moss, D., \& DeSanto, B. (2011). Public relations: A managerial perspective. London: SAGE Publications.

Must, O. (2016) Gümnaasiumite lisandväärtuse mudelid. Külastatud aadressil https://www.innove.ee/wp-content/uploads/2018/10/Gumnaasiumite-lisandvaartuse-mudelid_101016_V3.pdf 
OECD. (2009). Creating effective teaching and learning environments: First results from TALIS. OECD.

OECD. (2014). TALIS 2013 results: An international perspective on teaching and learning. OECD.

OECD. (2019). TALIS 2018 Results (Volume I): Teachers and school leaders as lifelong learners. OECD.

Ots, M. (Toim). (2019, 10. dets). Eesti paneb PISA tulemused riigi mainekujunduse heaks tööle. ERR. Külastatud aadressil https://www.err.ee/1012312/eesti-paneb-pisatulemused-riigi-mainekujunduse-heaks-toole

Porterfield, K., \& Carnes, M. (2012). Why social media matters: School communication in the digital age. Bloomington: Solution Tree Press.

Rawolle, S. (2010). Understanding the mediatisation of educational policy as practice. Critical Studies in Education, 51(1), 21-39.

https://doi.org/10.1080/17508480903450208

Salu, E. (2018, 31. aug). Miks õpetajad koolist lahkuvad? Õpetajate Leht, lk 8.

Senge, P. M. (2009). A Fifth discipline Resource: Oppiv kool. Tartu: Atlex AS.

Skallerud, K. (2011). School reputation and its relation to parents' satisfaction and loyalty. International Journal of Educational Management, 25(7), 671-686. https://doi.org/10.1108/09513541111172081

Smith, R. (2009). Strategic Planning for Public Relations. New York: Routledge.

Sutrop, M., Toming, H., \& Kõnnussaar, T. (2017). Hea kooli käsiraamat. Tartu: Tartu Ülikooli Kirjastus.

Tikerperi, M. L. (2016). Suhtekorraldus ja kommunikatsioonijuhtimine koolis riigigümnaasiumite näitel. Magistritöö. Tartu Ülikool, haridusteaduste instituut.

Türk, K., Haldma, T., Kukemelk, H., Ploom, K., Irs, R., \& Pukkonen, L. (2011). Üldharidus-ja kutsekoolide tulemuslikkus ja seda mõjutavad tegurid. Tartu Ülikool, Haridus- ja Teadusministeerium.

Uiboleht, U. (2019, 14. dets). Urmo Uiboleht: koolijuht ja -pidaja - kes keda? ERR. Külastatud aadressil https://www.err.ee/1013839/urmo-uiboleht-koolijuht-japidaja-kes-keda

Vaarik, D. (2014). Sõnumiseadja käsiraamat. Külastatud aadressil https://memokraat.ee/memokraat.ee/wp-content/uploads/2014/07/s\%C3\%B5numi seadjak\%C3\%A4siraamat.pdf

Valk, A. (2018). Rahulolu mõõtmine 2017. Õpilaste ja õpetajate heaolu üle-Eestilises rahuloluküsitluses, lühiülevaade 2017.a tulemustest. Ettekandeslaidid. Külastatud aadressil https://www.hm.ee/sites/default/files/rahulolu_2017.pdf

Vinter, K. (2014, 18. sept). Kool ja õpikäsitus peavad muutuma. Sirp. Külastatud aadressil https://www.sirp.ee/s1-artiklid/c9-sotsiaalia/2014-09-18-15-07-38/

Watson, T. (2012). The evolution of public relations measurement and evaluation. Public Relations Review, 38(3), 390-398.

https://doi.org/10.1016/j.pubrev.2011.12.018 


\title{
Looking for the "inexplicable something": which aspects form a school's reputation?
}

\author{
Mari-Liis Tikerperi ${ }^{\text {al }}$ \\ ${ }^{a}$ Institute of Social Studies, University of Tartu
}

\begin{abstract}
Summary
In the common use, the term "reputation" (also imago and image) is often referred to as an abstract evaluation while characterising institutions or individuals. In academic literature, reputation is more commonly related to studies in marketing, politics, management and organisation culture (da Camara, 2011; Skallerud, 2011). Several scholars have reported that nowadays,school leadership has changed, and general management skills have become more essential (Harris et al., 2003). Reputation is related to the satisfaction or "benefit" that an organisation can offer to its stakeholders (Brown et al., 2006; Gilpin, 2010; Helm, 2011) and schools should involve their interest groups (Kukemelk \& Ginter, 2016; Porterfield \& Carnes, 2012) for the purpose of school improvement. Moreover, in the situation of growing public interest in schools (Breiter \& Ruhe, 2018; Isaksson \& Enbom, 2015) and the competition between the schools (Bunar \& Ambrose, 2016; Isaksson \& Enbom, 2015; Türk et al., 2011), they have to prove their attractiveness.

Although it seems that nowadays it is easier to share information, many authors have noted that during the last decades, communication has changed due to the rapid developments in information and communication technologies (Porterfield \& Carnes, 2012; Watson, 2012). Changing media environment and mediatisation (Breiter \& Ruhe, 2018; Gilpin, 2010) are new challenges for schools as for any other organisation.

Estonia's reputation in general education has been due to the students' outstanding results in recent PISA tests, and highlighted in the national education marketing programme Education Nation (Ots, 2019). Also, in recent years, more attention has been paid to the reputation of the teaching profession. Foundation Innove has initiated annual school satisfaction surveys in grades 4,8 , and 11 as well as among teachers and parents. In those surveys, a school's reputation is associated with overall satisfaction and being proud of one's school (Lukk et al., 2016), but the content and meaning of the term "reputation" is not
\end{abstract}

Institute of Social Studies, University of Tartu, Lossi 36, Tartu, 53001 Estonia; mari-liis.tikerperi@ut.ee 
explained. In public discussions, some aspects of school reputation, such as the academic results, renovated buildings, famous alumni and active students are often referred to and described (Heinaru, 2016; Kasemägi, 2018; Kukin, 2018). All these approaches are quite different and do not explain the detail, or depth of the schools' reputation.

A reputation management scholar Sabrina Helm (2011) has analysed different definitions of reputation and indicated seven main characteristic elements of reputation: a) perceptual element, b) time perspective, c) stakeholder affiliation, d) reciprocity element, e) corporate performance, f) benefit or "customer" value element and g) competitive advantage.

Building on the existing body of knowledge, this paper aims to elaborate on these mapped elements of reputation by trying to describe and organise the specific aspects influencing schools' reputation. Given that reputation management is a part of general management and there are no common understandings and clearly measurable values in schools' reputation management strategies, the author decided to collect data by interviewing school leaders $(\mathrm{N}=19)$ from different Estonian basic and upper secondary schools. Transcribed interviews (470 pages) were analysed 1) inductively to find out how the principals describe school reputation and reputation management in general (RQ1) and then 2) deductively, to compare the aspects of school reputation, as described by principals, with theoretical definitions of reputation (RQ2). As a result, the author provides a framework for planning and managing reputation and communication in schools of general education by proposing different indicators that could help to specify an abstract notion. During the interviews, it was not considered important to measure the scope of the principals' theoretical knowledge about the topic, as the author was more interested in their reflections and experiences of different indicators enabling them to create the understanding about a school's reputation.

\section{Results}

The interviewed principals confirmed that schools are facing new demands and there is a growing need for professional and well-planned communication management. Most of the school leaders had felt more intensive public interest in their organisation and considered it essential to be visible, preferably about positive things. All the interviewed principals confirmed the importance of their interest groups, although they saw them in different positions and roles. In some schools some groups, for example parents or alumni, are involved in school's reputation management. In the schools, communication tasks are 
given to various employees, such as study coordinators, development/project managers, activity leaders or certain teachers (besides the principal).

The most valuable findings of the study are different indicators $(\mathrm{N}=46$; divided into seven categories according to Helm (2011)) which, based on the interviews, form the schools' reputation. For example, the principals believed the unity of "school-family" i.e. the number of different academic and free-time opportunities in school, close relationships with interest groups, cooperation with different firms and organisations, school's visual identity etc., to be essential (in addition to the aspects written above in the context of public discussion).

In addition to school-based indicators, also mentioned were some external aspects which may influence school's reputation, such as the imago of area and the principal's or teacher's personal reputation.

The main idea of exploring the indicators of school reputation was to offer more specific reputation-related aspects to simplify reputation management in schools. According to the interviewees most of the schools do not have the financial resources to hire communication professionals and consequently, reputation management is difficult. Those indicators can be seen as small inspiring tasks or aspects to follow, a checklist in reputation management. The principals did give some examples of activities performed with the main purpose of improving reputation but admitted that mostly, managing reputation is just a "side-effect" of everyday work.

To summarise, school's reputation is created by highlighting the school's achievements as well as recognising its failings, within the expectations of different stakeholders. However, while evaluating or trying to measure a school's reputation, it is essential to take into account the nature of school's main activities, the heterogeneity of parents as their main interest group, limited budget and different levels of communication skills.

Keywords: schools' reputation, school of general education, school satisfaction, school leadership, communication management in schools 